\title{
Pedagogical strategy for teaching and learning Epidemiology in Nursing undergraduate school
}

\author{
Estratégia pedagógica para o ensino-aprendizagem da Epidemiologia na Graduação em Enfermagem \\ Estrategia pedagógica para la enseñanza-aprendizaje de la Epidemiología en la Graduación en Enfermería
}

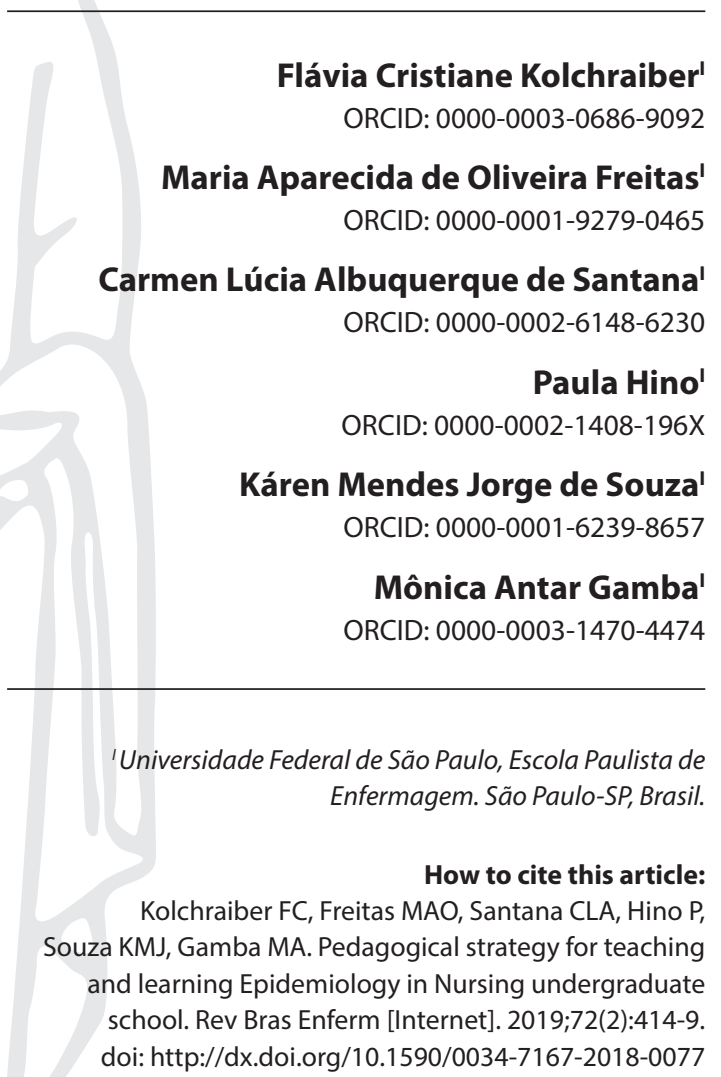

Corresponding Author:

Flávia Cristiane Kolchraiber

E-mail: flacrik@gmail.com

Submission: $02-19-2018$

Approval: 09-01-2018

\begin{abstract}
Objective: to implement a pedagogical strategy in the epidemiology course of a nursing school in a public university. Method: This is an interventional prospective study, with a critical epidemiological approach, based on the learner's worldview for a theoretical conception about science. The development of the study started from a field recognition for the systematization of the teaching-learning strategy and ended with the evaluation of the course. Results: 67 students participated in the study, 91\% were female and 54\% were between 20 and 29 years old. Prior knowledge was mostly clinical/biological, and the strategy used enhanced the knowledge of science in a critical, creative and reflective way, stimulating intersectionality and teamwork through the use of Information and Communication Technologies. Final Consideration: The pedagogical strategy provided a meaningful learning about the principles of epidemiology.

Descriptors: Epidemiology; Education, Nursing; Learning; Teaching; Public Health.
\end{abstract}

\section{RESUMO}

Objetivo: Implementar uma estratégia pedagógica na unidade curricular de Epidemiologia do curso de enfermagem de uma universidade pública. Método: Trata-se um estudo intervencional, prospectivo, sob o foco da Epidemiologia crítica, partindo da visão de mundo do educando para a concepção teórica sobre a ciência. O desenvolvimento teve como base o reconhecimento de campo para sistematização da estratégia de ensino-aprendizagem até a avaliação de unidade curricular. Resultados: Participaram 67 estudantes, $91 \%$ do sexo feminino e $54 \%$ entre 20 a 29 anos. O conhecimento prévio nos núcleos de significados foi majoritariamente clínico/biológico, em que a estratégia potencializou o conhecimento da ciência de forma crítica, criativa, reflexiva, estimulando a transversalidade e o trabalho em equipe pelo uso das Tecnologias de Informação e Comunicação. Considerações Finais: A estratégia pedagógica motivou os estudantes a uma aprendizagem significativa sobre os princípios da Epidemiologia.

Descritores: Epidemiologia; Educação em Enfermagem; Aprendizagem; Ensino; Saúde Pública.

\section{RESUMEN}

Objetivo: implementar una estrategia pedagógica en la unidad curricular de epidemiología de la carrera de enfermería de una universidad pública. Método: Se trata de un estudio de intervención, prospectivo, bajo el foco de la epidemiología crítica, partiendo de la visión de mundo del educando para la concepción teórica sobre la ciencia. El desarrollo de la investigación tuvo como base el reconocimiento de campo para sistematización de la estrategia de enseñanza-aprendizaje hasta la evaluación de unidad curricular. Resultados: Participaron 67 estudiantes, 91\% del sexo femenino y 54\% entre 20 a 29 años. El conocimiento previo en los núcleos de significados fue mayoritariamente clínico/biológico, donde la estrategia potenció el conocimiento de la ciencia de forma crítica, creativa, reflexiva, estimulando la transversalidad y el trabajo en equipo por el uso de las Tecnologías de Información y Comunicación. Consideraciones Finales: La estrategia pedagógica motivó a los estudiantes a un aprendizaje significativo sobre los principios de la epidemiología. Descriptores: Epidemiología; Educación en Enfermería; El aprendizaje; Educación; Salud Pública. 


\section{INTRODUCTION}

The social, political, economic, educational, biological and technological transformations of this day and age directly affected health care. Large population migrations, the struggle for racial and gender equality, occupations that are a result of changes in public policies, social exclusion manifested beyond the formal media, changes in the distribution of diseases, new possibilities for prevention, treatment and rehabilitation and the need for health promotion are all challenges for the field of Epidemiology ${ }^{(1)}$.

In addition, the exponential growth of information technology has increased the speed of access to knowledge, transforming work relationships and life in society and demanding constant updates and incorporation of new technologies in the work process in health and in the recognition of the genesis of the population's illness ${ }^{(2)}$.

Thus, understanding Epidemiology as a science that supports decision-making in the organization of actions developed in Public Health is essential for the training of future nurses.

Given the continuous social transformations, the different sciences, or the different types of knowledge, such as philosophical, scientific, technological, empirical and theological, must dialogue in order for society to reach more ethical, healthy and humane parameters, in an objective way and based on epistemological knowledge. Education has a crucial function in opening dialogues and has potential to raise awareness among educators and learners (the future professionals) about the importance of health assistance within this changing scenario ${ }^{(3-5)}$.

Epidemiology teaching in Brazil began in the 1920s and, since then, its importance for Public Health has been undeniable. Due to its relevance, it became a mandatory course in all undergraduate schools in the health area. The incorporation of this science in college curriculum and in Public Health in the subsequent years allowed for advancements that included the addition of this topic in postgraduate studies, the application of Biostatistics, stimulus to the use of technologies and strengthening of health planning and health care actions ${ }^{(6-7)}$.

The development of Epidemiology as a course and its epistemology were dissociated from the organization of health services and autonomy from other scientific fields. This becomes evident when discussing the importance of triangulation between education, sociology and medicine or health, going beyond medicine by itself. This integration proposal indicates a greater concern with a theoretical training dissociated from practice ${ }^{(7-10)}$.

In some scenarios, the academic environment delivers a fragmented scientific knowledge, focused on theory and using evaluations that assess the memorization of content. This teaching practice is non-critical and follows a traditional model and a content-focused teaching and learning method. It is centered on the role of the teacher and on the transmission of information, with little or no space for the development of new ways of learning. This teacher-centered approach is still very common in different levels of education. This often generates passive students, who take notes and memorize, instead of students who manage their reality with creativity and conviction and bring praxis learning to this process ${ }^{(10)}$.

Praxis is cited as a dimension that encompasses both the objective action of human beings and their subjective productions, articulating actions and intentions, such as overcoming alienation, that is, it is an action that transforms concrete existence into meaningful learning ${ }^{(11)}$.

International studies that investigated methods of epidemiology teaching that concatenate action and intention in the training of the health professional point out that a reorganization of basic epidemiology around the main concepts and principles can be an effective path. Research in nursing propose reorganizations of the teaching-learning process ${ }^{(12-16)}$.

Epidemiology teaching, due to its volume of content and its categorization as prerequisite in undergraduate programs in the area of health, commonly uses teaching strategies focused on theoretical content and that do not generate committed professionals, capable of acting on the determinants of the health-disease care process.

Given this scenario, the development of pedagogical practices that enable a meaningful learning of epidemiological concepts is necessary.

\section{OBJECTIVE}

To implement a problem-based teaching strategy for epidemiology teaching in a nursing undergraduate school of a Brazilian public university.

\section{METHOD}

\section{Ethical aspects}

The research complied with Resolution No. 510/2016 and 466/2012, both from the National Health Council, and was approved by the Research Ethics Committee of the University.

The anonymity of the participants was maintained. The students were given the option of not participating in the research, regardless of whether or not they were taking the course.

\section{Type of study and scenario}

This is an interventional, prospective study with a qualitative approach and an empirical analytical methodology. It was carried out in the epidemiology course (EC) of the undergraduate nursing school in a public university in the city of São Paulo - SP, from May 2015 to October 2016. The study population was composed of first-year students, men and women aged 18 years old or older who voluntarily accepted to participate in the research.

\section{Methodological procedures and organization of data}

Data were collected through self-report questionnaires that included: social, economic, racial and gender variables, description of the physical and organizational structure of the institution and monitoring and evaluation instruments consisting of open and closed questions and geospatial analysis, one with a continuous scale and the others with categorical scales, all created by the researcher.

\section{Data analysis}

Open answers were analyzed using Bardin's thematic content analysis technique. Innovative technological tools, free software 
and health information systems from the Health Ministry and Health Offices were used to create the database. All records were organized in Excel spreadsheets ${ }^{(17-18)}$.

\section{Stages of the study and theoretical and methodological framework}

The stages developed in the study were: identification of the teaching-learning process of epidemiology and selection of distinguished teaching strategies, after an integrative literature review and field recognition of the physical and organizational structure of the university, the Pedagogic Project of the Course (PPC) and the syllabus of the epidemiology course. For this stage, we conducted an unstructured observation of the physical spaces of the classes and an analysis of the PPC and of the contents of the EC, using as theoretical framework Paulo Freire's Liberating Education and Breilh's Critical Epidemiology ${ }^{(5,7,11)}$.

The implementation of the teaching strategy was evaluated by the students in individual self-evaluation activities and directed group activities, analyzing: case studies and databases elaborated by the students, epidemiological focus, measurement of health indicators with self-reported data and the presentation of seminars based on epidemiological data of vulnerable populations: refugees, riverside population, gender, ethnic and racial minorities, indigenous population, prison population, people in situations of violence or climatic catastrophe and those affected by chronic and infectious diseases or external causes.

\section{RESULTS}

All the first-year nursing students voluntarily participated in the present study. The sample was composed of 67 students, mostly females (91\%), predominantly between 20 and 29 years old (54\%).

A new course plan was elaborated, with the support and orientation of pedagogy professional, respecting the objectives of the EC and the total credit hours of the course. Based on the information generated in the data collection, the physical environments for the development of the EC were organized. After that, innovative information and virtual communication technologies were developed with the students and were later used in class.

The EC was divided in: four hours of practice in a computer lab, four hours of street research, 20 hours of presentation of seminars and guided activities, eight hours of dialogue and four hours for the self-evaluation of the students and the evaluation of the EC. The time used in communications via e-mail, social media and cellphone apps was not considered.

For the development of the EC, pedagogical and ethical contracts were established between educators and learners. The different opinions within the group and the objectives beyond this investigation were respected. Among the rules agreed upon, there were: not using virtual communication and cellphones during the classes, face-to-face and virtual contact between educators and learners to clarify any doubts, exchange of information, approximation, dynamism and creativity during the development of the activities, a break time during the classes, start and finish hours, behaviors and evaluations. In addition, a space to support students in their concerns was established.
The oral presentations were alternated with dialogue lectures, participatory activities, games, dynamics, videos, texts or music for reflection. The strategy chosen for the synthesis of the knowledge acquired in the EC and part of the evaluation was the presentation of seminars that addressed populations in situations of vulnerability.

The themes for the seminars were randomly distributed and the groups were defined by affinity. The students received orientations about the structure of the presentation and were encouraged to use creativity. The presentation dynamics were at the discretion of the groups. Some criteria were stablished: 40-minute presentations, participation of all members of the group and use of creativity as a driving force for learning. A written paper on the subject, with the perceptions of the group and respecting the academic norms of the institution, was also requested.

Several procedures were used by the groups, such as theater, creation of videos, interviews, presence of specialists (refugees, prison workers, professionals who work with indigenous populations, community leader, service users and representatives of groups in situation of vulnerability, among others) and of the academic community to participate and contribute on the theme, use of information technologies (apps, games, social media, creative programs for presentations), and development of research in schools and in the street to re-signify theory.

This moment allowed debates on current issues in a democratic teaching-learning environment, stimulated research and extension and highlighted the relationship between theory and practice. This educational approach encouraged students to participate in discussion groups on the subject in academic extension programs (research, outreach, scholarships and tutoring center).

External activities were divided in street and laboratory research. For street research, the students received orientations for the use of the instrument elaborated for data collection, which included health, socio-demographic, economic and morbidity self-reported variables. They were also oriented to use the virtual tools and had the opportunity to carry out a field research. The analysis of the data from the street research allowed them to understand interviewer training, epidemiological terminology, variables related to territory, time, individuals and population, applicability to calculate the main health indicators, the types of epidemiological studies, sample size and the need for reliable data collection. The work developed in the computer lab provided knowledge on the main sources of epidemiological data and their use to elaborate seminars.

The topics covered in the course included basic knowledge in Epidemiology, such as: health indicators, causality, Epidemiology concepts, epidemiological studies, errors and bias, analysis of socio-demographic data, vulnerable populations, health care networks, social determinants of health, among others (Chart 1).

With these innovative technologies and with the apprehension of the content of the EC, it was observed that $80 \%$ of the students reached a knowledge considered satisfactory according to what is expected for their educational performance.

As for the teaching strategy used, 101 citations were found in the database, 30 (29.7\%) related to critical reflection, $27(26.7 \%)$ to motivation, 24 (23.7\%) to teamwork, and 20 (19.8\%) to love, humanization, among others. Some students reported: 
Chart 1 - Distribution of the syllabus of the Epidemiology course, São Paulo, Brazil, 2015

\begin{tabular}{|c|c|c|}
\hline Topic covered & Content & Activity \\
\hline $\begin{array}{l}\text { Presentation of } \\
\text { the course and } \\
\text { pedagogical and } \\
\text { research strategies }\end{array}$ & $\begin{array}{l}\text { Who are we? Who } \\
\text { are you? How can } \\
\text { we contribute to our } \\
\text { teaching-learning } \\
\text { process? }\end{array}$ & $\begin{array}{l}\text { Learning with } \\
\text { you }\end{array}$ \\
\hline $\begin{array}{l}\text { Epidemiology: } \\
\text { history, objectives, } \\
\text { theoretical } \\
\text { landmarks and } \\
\text { Epidemiology } \\
\text { concepts }\end{array}$ & $\begin{array}{l}\text { Introducing the subject. } \\
\text { Our starting question. }\end{array}$ & $\begin{array}{l}\text { Information from } \\
\text { the students and } \\
\text { street research }\end{array}$ \\
\hline $\begin{array}{l}\text { Epidemiology and } \\
\text { Collective Health: } \\
\text { health-disease-care } \\
\text { model }\end{array}$ & $\begin{array}{l}\text { "Epidemiology: natural } \\
\text { history of disease, } \\
\text { health care networks, } \\
\text { social determinants } \\
\text { and determinants of } \\
\text { the health-disease-care } \\
\text { process." }\end{array}$ & $\begin{array}{l}\text { Chat with } \\
\text { specialist. } \\
\text { Vulnerable } \\
\text { populations and } \\
\text { health problems. }\end{array}$ \\
\hline $\begin{array}{l}\text { How to measure } \\
\text { health problems. } \\
\text { Health indicators: } \\
\text { turning numbers } \\
\text { into actions }\end{array}$ & $\begin{array}{l}\text { Research on health } \\
\text { information systems. } \\
\text { Health determinants } \\
\text { and health indicators }\end{array}$ & $\begin{array}{l}\text { Computer lab, } \\
\text { research on DATA } \\
\text { SUS, TABNET, } \\
\text { SIAB, e SUS, } \\
\text { OPAS, OMS. }\end{array}$ \\
\hline $\begin{array}{l}\text { Incidence and } \\
\text { mortality studies }\end{array}$ & $\begin{array}{l}\text { I want to share what I } \\
\text { have researched and } \\
\text { what I am learning. } \\
\text { The indicators we see } \\
\text { and hear in various } \\
\text { subjects. Territory and } \\
\text { vulnerability. }\end{array}$ & $\begin{array}{l}\text { Presentation of } \\
\text { seminars: } \\
\text { Prison } \\
\text { population/ } \\
\text { Recurring and } \\
\text { neglected } \\
\text { diseases }\end{array}$ \\
\hline $\begin{array}{l}\text { Cross-sectional } \\
\text { studies }\end{array}$ & $\begin{array}{l}\text { I want to share what I } \\
\text { have researched and } \\
\text { what I am learning. } \\
\text { Studying the moment. }\end{array}$ & $\begin{array}{l}\text { Presentation } \\
\text { of seminars: } \\
\text { Indigenous } \\
\text { population/ } \\
\text { Chronic Non- } \\
\text { Communicable } \\
\text { Diseases }\end{array}$ \\
\hline $\begin{array}{l}\text { Epidemic and } \\
\text { endemic studies }\end{array}$ & $\begin{array}{l}\text { I want to share what I } \\
\text { have researched and } \\
\text { what I am learning. } \\
\text { The concepts that } \\
\text { go beyond these } \\
\text { situations. }\end{array}$ & $\begin{array}{l}\text { Presentation } \\
\text { of seminars: } \\
\text { Refugees/ } \\
\text { Emerging } \\
\text { diseases }\end{array}$ \\
\hline $\begin{array}{l}\text { Incidence and } \\
\text { prevalence studies }\end{array}$ & $\begin{array}{l}\text { I want to share what I } \\
\text { have researched and } \\
\text { what I am learning. The } \\
\text { indicators we see and } \\
\text { hear in various subject. }\end{array}$ & $\begin{array}{l}\text { Presentation } \\
\text { of seminars: } \\
\text { Riverside } \\
\text { population/ } \\
\text { Health, } \\
\text { environment, } \\
\text { endemics and } \\
\text { catastrophes }\end{array}$ \\
\hline Cohort studies & $\begin{array}{l}\text { I want to share what I } \\
\text { have researched and } \\
\text { what I am learning. } \\
\text { Towards the situation } \\
\text { or the event: what do I } \\
\text { observe first? }\end{array}$ & $\begin{array}{l}\text { Presentation of } \\
\text { seminars: Black } \\
\text { Population/ } \\
\text { Gender Issues, } \\
\text { External Causes. }\end{array}$ \\
\hline $\begin{array}{l}\text { Ending, evaluation } \\
\text { and self-evaluation }\end{array}$ & $\begin{array}{l}\text { Our exchange of } \\
\text { knowledge }\end{array}$ & $\begin{array}{l}\text { Solving } \\
\text { problems: Haiti is } \\
\text { here! }\end{array}$ \\
\hline
\end{tabular}

I know that after these classes I was no longer the same.

In this course I also had experiences with group work, and I learned to deal with each quality and flaw of my colleagues and of myself.

I really enjoyed the learning process, which was not focused on a teacher-student model, but on conversations and dynamic learning.

The games, dynamics, videos and questioning used as teaching strategies by the groups in their seminars contributed to this success.

Four theoretical bases were fundamental to the development of this pedagogical practice: meaningful learning, expanding horizons, continuity and love.

Meaningful learning suggests that the topics addressed must make sense for both educators and learners, and the lessons of the course should align the desires and expectations of both. Therefore, it is considered re-learning, since it is based on the assumption that the student has previous knowledge on the subject and, with new stimuli, can deconstruct to reconstruct the concepts and their forms of application. The expansion of horizons or new repertoire contribute to the development of individual and collective views among educators and learners about their practices and their insertion in health care. Continuity refers to the fact that the teaching-learning process has no beginning or end and that everyone has the knowledge to build new practices in work and in relationships. In addition, people should be encouraged to continue learning in a systematic way throughout their lives. Finally, love is related to the fact that working with emotions strengthens the teaching-learning process, having a positive impact on behavior changes ${ }^{(19-20)}$.

\section{DISCUSSION}

The implementation of the Epidemiology course allowed the development of a teaching-learning strategy capable of enhancing the education of these students, stimulating the desire to learn and the curiosity to understand the contribution of Epidemiology to the area of health, respecting the generational characteristics, and thus allowing a historically constructed and contextualized education.

The inclusion of elements of active learning in the teaching-learning of Epidemiology improves learning and increases interest in class, but requires more time for preparation. Despite the relevance of the development of this new teaching-learning process, it is worth emphasizing that making changes is a challenge within education structures that focus predominantly on technical-scientific knowledge.

Teaching requires conviction that change is possible. Teaching is intervening in the reality not only of the learner, but also of the educator who does not settle, who understands that an ethical formation must be technically consistent in order to help the population, but must also be reflective and able to transform society ${ }^{(20-21)}$.

It is also worth noting that a dialogic approach in the organizational and physical structure is an issue that must be studied to enhance the teaching-learning process. In health education, the focus on the development of the technical skills required by the labor market, without integration with other competences 
(knowing how to be, knowing how to interact, knowing how to know), can weaken the general proposal of the Institutional Pedagogical Project and limit teaching, not contributing to the training of critical professionals, except from the technical point of view.

Education in the area of health should be aimed at transforming professional practices and the organization of work and should be structured based on questioning the process. In this sense, the students must be protagonists in the teaching-learning process, so that they can later contribute to the improvement of work processes, expanding their work and action with and for society. In this way, the students must become an active part in the process of knowledge production, going beyond the predefined curriculum and bringing proposals that are appropriate to their interests and practice ${ }^{(22-23)}$.

This prominent role, especially in Epidemiology, requires more time to acquire knowledge and incorporate a science that is a basis of Public Health and that will be used throughout the entire professional practice of nurses. It is important to highlight the improvements provided by the Collective Health course and by the practical activities developed in basic health units, which should constitute the praxis in collective health, re-signifying practice through a careful analysis of social determination and vulnerability criteria with attention focused on Health Promotion actions ${ }^{(5,24)}$.

The approximation between the teaching-learning approach for Epidemiology and Collective Health has become a strictly clinical and a productivism practice, which focuses on illness and turns the students' attention to a practical field focused on comprehensive care. The university has a fundamental role in the socialization of students who are learning Epidemiology, as it allows recognizing professionals who work according to Public Health values and provides community experiences in practice and the exercise of non-specialization, that is, expanding horizons without losing focus in the human being ${ }^{(25)}$.

\section{Limitations of the study}

Despite the scarcity of studies on this subject, it was observed that teaching is centered on content approaches and that science centered on epidemiological rationality is still the focus of the teaching-learning process in nursing curricula, with insufficient credit hours, a vertical curriculum and no articulation between different knowledges. Moreover, the method used does not allow the application of these findings in other scenarios and the results may not be transforming elements for educational practice.

\section{Contributions to the area of nursing and public health}

Although there are few existing studies about the teachinglearning of Epidemiology in Nursing programs, an effective systematization of pedagogical strategies, through teaching based on meaningful learning, expanding horizons, continuity and love, has the potential to increase curiosity for learning this science and interest in the subject and, thus, can contribute to generating more critical, creative and active professionals.

In short, Nursing education institutions, after curricular changes, have the potential to implement the teaching-learning of Epidemiology and to offer to the population and to health services professionals that are more prepared to act in the context of the Unified Health System.

\section{FINAL CONSIDERATIONS}

The pedagogical strategy evaluated has the potential to contribute to having more engaged, creative, critical and proactive professionals.

This study allowed observing the transformation of a technical and content-focused model into a democratic and transformative model. However, this requires educators to seek changes beyond an adequate structural support. The study also reinforced the value of dialogue in the teaching-learning of the EC, pointing to the effectiveness of Information and Communication Technologies (ICTs) in promoting active learning.

The study indicates the need for more studies on the teachinglearning of Epidemiology, based on pedagogical strategies that can enhance the student's performance, in a partnership with the educator, with topics that discuss territory, vulnerability, risks and Global Health.

It is a clear responsibility of the university to deepen knowledge on "learning to learn" in order to be able to teach in a responsible way and in complicity with the student, through a cross-sectional curriculum that integrates different courses and allows the communication and visualization of the sciences in the knowledge and practice of educators and learners.

This research indicates that the creation of a specific dialogic model as a guide for teaching through $\mathrm{MECL}$ - Meaningful learning, Expanding horizons or new repertoires, Continuity and Love - meets the need for changes in nursing education in order to act in the health-disease-care process of individuals and communities, and, more than that, responds to the question asked by Paulo Freire "Educate for what?" or, in this context, "Epidemiology for what?"

\section{ACKNOWLEDGEMENTS}

We thank Prof. Ausônia Favorido Donato for all her support and encouragement to loving reflection. The 76th Class of Nursing of the EPE for all their commitment and collaboration in teaching and learning in an organic way.

\section{REFERENCES}

1. Araújo JD. Polarização epidemiológica no Brasil. Epidemiol Serv Saúde [Internet]. 2012[cited 2016 Sep 5];21(4):533-8. Available from: http:// scielo.iec.pa.gov.br/pdf/ess/v21n4/v21n4a02.pdf

2. Lima KWS, Antunes JLF, Silva ZP. Percepção dos Gestores sobre o uso de indicadores nos serviços de saúde. Saúde Soc [Internet] 2015[cited 2016 Sep 5];24(1):1. Available from: http://dx.doi.org/10.1590/S0104-12902015000100005 
3. Barata RB, Santos RV. Ensino de pós-graduação em Saúde Coletiva: situação atual e desafios para o futuro. Rev Bras Pós-Grad[Internet]. 2013[cited 2017 Jun 11];10(19):159-83. Available from: ojs.rbpg.capes.gov.br

4. Osmo A, Schraiber L. The field of Collective Health: definitions and debates on its constitution. Saúde Soc [Internet]. 2015 [cited 2017 Feb 23];24(supl-1):201-14. Available: http://www.scielo.br/pdf/sausoc/v24s1/en_0104-1290-sausoc-24-s1-00205.pdf

5. Breilh J. Epidemiologia crítica: ciência emancipadora e interculturalidade. Rio de Janeiro: Fiocruz; 2006. 317p.

6. Martínez MA, Miranda MD, Crespo TY. Abraham Flexner, Benjamin Bloom y Fidel Ilizástigui Dupuy: paradigmas de la educación médica americana. Rev Ciênc Med [Internet]. 2013[cited 2016 Jun 29];17(6):202-16. Available from: http://scielo.sld.cu/pdf/rpr/v17n6/rpr20613.pdf

7. Morabia A. Reflexões históricas ao redor do livro Epidemiologia \& Saúde: Fundamentos, Métodos, Aplicações Cad Saúde Pública[Internet]. 2013[cited 2017 Mar 6];29(6):1059-62. Available from: http://www.scielo.br/pdf/csp/v29n6/a03v29n6.pdf

8. Paim JS. Epidemiologia e planejamento: a recomposição das práticas epidemiológicas na gestão do SUS. Ciênc Saúde Colet [Internet]. 2003[cited 2017 Mar 5];8(2):557-67. Available from: http://www.scielosp.org/pdf/csc/v8n2/a17v08n2.pdf

9. Paim JS, Pinto ICM. Graduação em Saúde Coletiva: conquistas e passos para além do sanitarismo. Tempus (Brasília) [Internet]. 2013 [cited 2017 Mar 5];7(3):13-35. Available from: http://www.scielo.br/pdf/sausoc/v25n2/1984-0470-sausoc-25-02-00369.pdf

10. Schraiber LB, Mota A. O social na saúde: trajetória e contribuições de Maria Cecília Ferro Donnangelo. Ciênc Saúde Colet[Internet]. 2015[cited 2016 Oct 20];20(5):1467-73. Available from: http://www2.fm.usp.br/gdc/docs/cseb_25_cecilia_donnangelo.pdf

11. Freire P. Pedagogia da Autonomia: saberes necessários à prática da autonomia. São Paulo (SP): Paz e Terra; 2013.

12. David HMSL, Acioli S. Mudanças na formação e no trabalho de enfermagem: uma perspectiva da educação popular e de saúde. Rev Bras Enferm [Internet]. 2010[cited 2017 Mar 12];63(1):127-31. Available from: http://www.scielo.br/pdf/reben/v63n1/v63n1a21.pdf

13. Keyes KM, Galea S. Current practices in teaching introductory epidemiology: how we got here, where to go. Am J Epidemiol [Internet]. 2014[cited 2017 Feb 23];180(7):661-8. Available from: https://www.ncbi.nlm.nih.gov/pmc/articles/PMC4481568/pdf/kwu219.pdf

14. Caron RM. Teaching epidemiology in the digital age: considerations for academicians and their students. Ann Epidemiol [Internet]. 2013[cited 2017 Jun 26];23(9):576-9. Available from: http://www.annalsofepidemiology.org/article/S1047-2797(13)00161-0/pdf

15. Sistrom MG. Teaching epidemiology: the role of the public health nurse. J Nurs Educ [Internet]. 2008 [cited 2017 Jun 26];47(5):227-30. Available from: https://www.ncbi.nlm.nih.gov/pubmed/18522155

16. Majima Y. Development and evaluation for active learning instructional design of epidemiology in nursing informatics field. Nurs Inform[Internet]. 2016 [cited 2017 Jun 18]. Available from: http://www.kis.osakafu-u.ac.jp/osakafu-content/uploads/sites/151/2015/06/ NI2016-Majima.Development-.pdf

17. Bardin L. Análise de conteúdo. Lisboa (PT): Edições 70; 2004.

18. Vieira S. Como elaborar questionários. São Paulo (SP): Atlas; 2009.

19. Ministério da Educação (BR). Parecer do Conselho Nacional de Educação, Câmara de Educação Superior n. 1.133/2001 Diretrizes Curriculares Nacionais dos Cursos de Graduação em Enfermagem, Medicina e Nutrição. Despacho do Ministro em 1/10/2001, publicado no Diário Oficial da União de 3/10/2001, Seção 1E, p. 131. Available from: http://portal.mec.gov.br/dmdocuments/ces1133.pdf

20. Freitas MAO, Cunha ICKO, Batista SHSS, Rossit RAS. Teaching in health: perceptions of graduates of a Nursing specialization course. Interface Comum Saúde Educ [Internet]. 2016[cited 2017 Jul 02];20(57):427-36. Available from: http://www.scielo.br/pdf/icse/v20n57/en_1807-5762icse-1807-576220150391.pdf

21. Pereira ALF. As tendências pedagógicas e a prática educativa nas ciências da saúde Cad Saúde Pública [Internet]. 2003 [cited 2017 Jan 20];19(5):1527-34. Available from: http://www.scielo.br/pdf/csp/v19n5/17825.pdf

22. Gusmão RC, Ceccim RB, Drachler ML. Tematizar o impacto na educação pelo trabalho em saúde: abrir gavetas, enunciar perguntas, escrever. Interface Comum Saúde Educ [Internet]. 2015 [cited 2017 Mar 20];19(Supl-1):695-707. Available from: http://www.scielo.br/pdf/icse/ v19s1/1807-5762-icse-19-s1-0695.pdf

23. Lima JF, Carpim L, Behrens MA. O professor universitário construindo conhecimentos inovadores para uma prática complexa, colaborativa e dialógica. Rev Diálog Educ [Internet]. 2017 [cited 2017 Mar 25];13(38):69-84. Available from: https://periodicos.pucpr.br/index.php/ dialogoeducacional/article/viewFile/7829/7562

24. Akerman M, Fischer A. National Agenda of Priorities in Health Research (NAPHR): focus on agenda 18 - Health Promotion. Saúde Soc [Internet]. 2013[cited 2016 Dec 5];23(1):180-90. Available from: http://www.scielo.br/pdf/sausoc/v23n1/en_0104-1290-sausoc-23-01-00180.pdf

25. Almeida-Filho N, Barreto ML, Veras RP, Barata RB. Teoria Epidemiológica hoje: Fundamentos, Interfaces, Tendências. Rio de Janeiro (RJ): Fiocruz; 1998. 